\title{
Building learners' academic autonomy based on textbook series for studying German «Im Klartext A2»
}

\author{
Evgenia A. Zimina (a), Julia E. Mueller (b) ${ }^{*}$, Olga V. Printsipalova (c) \\ (a) Moscow State Institute of International Relations (University) \\ Vernadskogo Av., 76, Moscow, Russia, 119454 \\ (b) Moscow State Institute of International Relations (University) \\ Vernadskogo Av., 76, Moscow, Russia, 119454 \\ (c) Moscow State Institute of International Relations (University) \\ Vernadskogo Av., 76, Moscow, Russia, 119454, \\ j.mueller@my.mgimo.ru
}

\begin{abstract}
Cardinal transformation in the education system transfers the mode of education participants to a higher level of a learner's individual responsibility for the academic results. In this respect, academic autonomy has a special significance together with its realization in the education system and its relevance for textbook series. The article gives the structure and content analysis of «Im Klartext A2» as a new generation educational kit. The purpose is to single out components for a learner's independent work to form academic autonomy skills. To perform the research content and structure analysis methods were applied as well as a classifying one. The result of the research is defining the task types possible to exploit as part of learners' individual class work. Most exercises and tasks from the workbook are to do as home task, their correctness is checked by keys. The workbook also contains tests with keys and a selfassessment scheme, which encourages development of self-assessment and reflection skills. The curriculum aimed at pronunciation, auditive and speech skills development is duplicated on the multimedia education platform ed.mgimo and enables learners to portion the material for revision and mastering skills by themselves, which leads to individualization of studies. The research data and results may be taken as a starting point of present textbooks and educational kits' analysis to take out the components possible to use as learners' independent work and, further on, to heed in the new educational training kit concept.

Key words: German as foreign language; textbooks; learner autonomy
\end{abstract}

\section{(C) 2021 Evgenia A. Zimina, Julia E. Mueller, Olga V. Printsipalova}

This is an open access article distributed under the terms of the Creative Commons Attribution License (CC BY 4.0), which permits unrestricted use, distribution, and reproduction in any medium, provided the original author and source are credited.

Published by Moscow City University and peer-reviewed under responsibility of TSNI-2021 (Textbook: Focus on Students' National Identity)

\footnotetext{
* Corresponding author. E-mail: j.mueller@my.mgimo.ru
} 


\section{Introduction}

In modern conditions of constantly accelerating science and technology progress and access to a growing amount of knowledge and modern IT technologies cooperation with all spheres of social life, self-education and relevant skills are becoming one of the main education targets. Another trend in modern education is variability of its forms. With digital technologies' growth to the traditional full-time, part-time education and correspondence studies (evening classes) there added various types of distant education which totally differ the ways of cooperation of those involved into the educational process. The focus is shifted from a teacher to the content to master and learners' interaction. The teacher supports new knowledge obtaining progress and development of the possessed one (Brash \& Pfeil, 2018). All that encourages the level of selfresponsibility for the education results and leads to necessity to work out methodology of autonomy and its application in higher education as a theoretical notion, on the one hand, and heeding this pillar of education in compiling new generation textbooks, educational aids and training kits, on the other.

\section{Purpose and objectives of the study}

The research purpose is to examine the «Im Klartext A2» structure and content as a new generation educational series to single out the components meant for learners' independent work and building their academic autonomy. To realise the purpose exercises and tasks are grouped according to the criteria of a social form, curricular or extra-curricular work, a teacher's assessment. Modules hosted on a digital education platform are considered as a possibility to be part of the educational training kit.

\section{Literature review}

Since the beginning of the 2000s Russian Education Science and Foreign Language Learning Methodology theoreticians and practicians have been paying close attention to the matter of academic self-sufficiency and autonomy. Kapaeva, A.E. (2001) delineated three phases of academic autonomy within foreign language learning: from imitating and thoughtful copying a teacher's actions with the usage of the mastered activities in the relevant conditions to skill transference into different situations. Meanwhile there is a transition from inner to outer motivation as well as building of self-regulation at a higher level. Tareva, E.G. and Yazykova, N.V. (2018) consider academic autonomy as a notion within the anthropocentric education paradigm. Emphasizing the fact that foreign language is not just a subject but also a means for "self-development, self-determination, self-identification in society, everyday life and future profession", the researchers underline the importance of learning foreign language for a learner personality with its individual character. Academic autonomy according to the authors makes learners build a skill of setting 
and getting objectives, take and realise responsible decisions. Thus, a learner gains an individual experience of result framework, reflection, and self-assessment. Solovova, E.N. (2013) giving a perspectives of higher education methodology for teaching foreign languages points out the Federal State Educational Standard provides for 50 percent contact training and 50 percent of independent work at the Bachelor level, with the gradual growth of the latter in Master and post graduate educational programs together with sophistication of studied material and, at the same time, the amount of a students', master candidates' and post-graduates' work regulated by teachers and scientific supervisors falls down. The author suggests intensification of using IT technologies for involving students, teachers and other specialists into interaction thus introducing some novelty into the traditional teacher-student interaction pattern. Giving analysis of various interpretations of the notion "academic autonomy" by foreign and domestic researchers, Nasonova, E.A. (2010) concludes that most researchers define the notions of "independence" and "autonomy" as synonyms and provide "self-education" as a term with a close meaning. Moreover, the author formulates academic autonomy development strategies which are possible to unite within the concise phrase 'to teach to learn'. A teacher instructs students how to single out what is to learn, helps to work out methods, patterns, and ways to cover material as well as reports how to assess self-education progress. The author notes that the notion of academic autonomy, in broad sense, includes the components of positive attitude to selfeducation, correlation of the chosen material and your own experience, interests and needs, ability to critically view activity results. Anikina, Zh.S. (2011) considers academic autonomy one of the most essential components of foreign language teaching and highlights three important criteria: psychological which incorporates motivation, reflection, self-regulation, and self-assessment; methodological which means mastering strategies and techniques of self-education; communicative which is a skill to talk over emergent difficulties and questions with other participants of the educational process. As the analysis result of the numerous works by foreign and domestic researchers Anikina, Zh.S. offers the following definition of academic autonomy which we are going to rely on in our work: academic autonomy is "a learner's ability... to independently set an objective of his activity, plan his actions, choose methods of educational activity and patterns of work, at the same time performing reflection, self-assessment and self-correction, besides, taking full responsibility for his education achievements and transferring them into a new training context."

\section{Methodology}

For performing the research there were used methods of content and structure analysis together with a classifying method. The subject studied is an educational training kit (ETK) for studying German for students of higher education "Im Klartext A2", which was worked out within communicative-action and competence approaches in foreign language teaching. This ETK builds A2 competences according to the 
Common European Framework of Reference for Foreign Languages. As part of the research, materials are classified as the classwork ones for individual, group work or work in pairs and materials for individual work that is possible for self-assessment or a teacher's estimation.

\section{Results}

The current educational training kit is compiled from both obligatory consistent parts, that is a textbook, workbook, audiotexts and video pieces on different storage devices, and as for the optional ones, they are bilingual glossaries, online exercises, supplementary materials, files for interactive board practice (Rösler \& Würffel, 2020). The ETK «Im Klartext A2» (2021) edited by Zimina E.A. is compiled from a student's book (Printsipalova, Merkish, Kirina), workbook (Omelchenko, Khosainova, Mueller), multimedia programme for class practice and a course for pronunciation, auditive and speech skills and competence development based on the multimedia educational platform ed.mgimo.

The student's book (Kursbuch) has seven chapters with a specific structure and is mainly meant for in-class practice. Nevertheless, the student's book structure analysis made available the components possible for individual independent work. The common peculiarity of such tasks is the optional character of a teacher's control at each stage of a student's work, but it is possible to check just the results. The given type of tasks is registered in Table 1.

Table 1. Individual work tasks of the student's book

\begin{tabular}{|l|c|c|c|c|c|c|}
\hline \multirow{2}{*}{ task type } & \multicolumn{3}{|c|}{ social form } & way of performing & result check \\
by teacher \\
\cline { 2 - 7 } & individual & in pairs & $\begin{array}{l}\text { in small } \\
\text { groups }\end{array}$ & in class & at home & \\
\hline $\begin{array}{l}\text { section 'It's } \\
\text { interesting' }\end{array}$ & + & & & & + & - \\
\hline $\begin{array}{l}\text { mini dialogues, } \\
\text { interview }\end{array}$ & & + & & + & & +- \\
\hline discussion & + & & + & + & & +- \\
\hline e-mails, blogs & + & + & + & + & + & + \\
\hline ads, paper news & + & & & & + & + \\
\hline $\begin{array}{l}\text { singling out } \\
\text { information from text }\end{array}$ & + & & & & + & + \\
\hline translation in writing & + & & & & & + \\
\hline
\end{tabular}




\begin{tabular}{|l|l|l|l|l|l|l|}
\hline $\begin{array}{l}\text { oral translation in } \\
\text { tandem }\end{array}$ & + & & + & & - \\
\hline
\end{tabular}

The section 'It's interesting' in Russian begins every chapter and provides cultural and country studies' information to build country studies competence.

Mini dialogues for automatic use of grammar structures in the classical model question/answer or stimuli/reaction and in the game format of 'information gap' meant for autonomous practice in pairs within class work and performed under minimal supervision by a teacher. An example of tasks for building oral speech skills is a picture description, an interview for autonomous work in pairs, a discussion for autonomous work in small groups. Work in pairs and small groups models real communication thus encouraging speech competence development (Feick, 2020).

Many tasks for written speech may be performed both individually and in pairs or small groups. Individual work results are handed in for being checked by a teacher, and texts compiled in pairs or small groups, such as ads or biographies, may be presented orally in class.

Written Russian-German translation tasks are contextually bound texts of a small size and various genres: information leaflets, brochures, interviews, blogs, biographies, etc. For translation, students are recommended to use on-line dictionaries as leodict, pons, context search systems as reverso context or linguee and warned of thoughtless use of automatic translators giving wrong and clumsy interpretation examples.

Oral Russian-German translation tasks performed on the spot and in tandem are compiled from contextually bound mini-texts in Russian with the given German translation in the opposite column, moreover, Russian, and German texts are alternated in chequerwise. Each of the partners in the pair covers a part of the table, one does the left side, the other - the right one. The partner who has the Russian text in front of his eyes translates it into German out loud. The other checks the correctness using the German variant. The next Russian text is given by the other partner and is checked by the first. The checking function is totally in charge of students who work in pairs. The teacher limits the time and observes the whole group practice. The given task is possible to perform both in-class and students' independent practice, in pairs or individual. Within an individual practice a student translates texts from Russian into German out loud and gradually opens the opposite German text for self-checking. Picture 1 gives the present type tasks' layout. 
Pic. 1

\begin{tabular}{|c|c|}
\hline $\begin{array}{l}\text { Kilian möchte seinen persönlichen Stil } \\
\text { verändern, das ist ihm sehr wichtig. Er } \\
\text { ist zu einem Modeberater gefahren und } \\
\text { hat mit ihm über sein Aussehen } \\
\text { gesprochen. Nach diesem Gespräch ist } \\
\text { Kilian einkaufen gegangen. }\end{array}$ & $\begin{array}{l}\text { Килиан хочет изменить свой } \\
\text { индивидуальный стиль, это очень } \\
\text { важно для него. Он поехал к } \\
\text { консультанту и поговорил с ним про } \\
\text { свой внешний вид. После этого } \\
\text { разговора Килиан отправился за } \\
\text { покупками. }\end{array}$ \\
\hline $\begin{array}{l}\text { Килиан выбрал интенсивные цвета и } \\
\text { хотел бы их комбинировать. Он купил } \\
\text { модные вещи. Его новый костюм очень } \\
\text { ему идет, а новый галстук просто } \\
\text { превосходен. }\end{array}$ & $\begin{array}{l}\text { Kilian hat intensive Farben gewählt und } \\
\text { möchte sie kombinieren. Er hat } \\
\text { modische Sachen gekauft. Sein neuer } \\
\text { Anzug steht ihm sehr gut, und seine neue } \\
\text { Krawatte ist einfach perfekt. }\end{array}$ \\
\hline Heute geht Kilian mit seiner Fre & Сегодня К \\
\hline
\end{tabular}

The workbook (Arbeitsbuch) as well as the student's book has seven chapters and is compiled from exercises for building lexical and grammar skills hence aiming at forging linguistic competence. Besides, in the workbook there are deployed additional texts with content comprehension tasks and drill tests with keys for self-assessment and result framework giving students a general idea of the tasks from in-class tests. Self-assessment skills are essential parts of academic autonomy. (Grotjahn \& Kleppin, 2018).

In the groups with «Im Klartext A1» experience students are familiar with most types of exercises and tasks from the workbook. Students who worked with different textbooks at the previous level are necessary to introduce to the exercise types and translate together the assignments. Independent practice based on the workbook demands a student's linguistic competence at a definite level, that is, in particular, morphology and syntax terminology understanding. During the first classes the teacher is recommended to comment on the core types of exercises, if necessary, remind students the meaning of some notions.

To build grammar skills there are offered the following exercises: filling gaps with verb, noun and adjective affixes; filling gaps with words in the initial form - infinitives, nouns and personal pronouns' nominative case, adjectives in the short form - in the relevant time/tense, person, number, case; classification of nouns according to their grammar gender, plural number type, verbs as to their three main forms; choosing a modal or auxiliary verb; completing a sentence with a given word combination; sentence transformation to use another verb form (number, person, tense, voice, mood); matching sentence parts as to their sense; filling in prepositions, articles, conjunctions; compiling a complex coordinate and 
subordinate sentence from two simple ones; choosing one of the many possible conjunctions/prepositions; sentence transformation based on synonymic conjunctions (tense, voice, mood).

The following types of exercises are offered to build lexical skills: matching a picture with a lexical unit; filling gaps with nouns to complete the meaning of a sentence; filling gaps with synonyms or antonyms in word-combinations and sentences; people, objects, weather, etc. description with the help of adjectives; building compound nouns and adjectives; matching word-combinations of the given parts.

To build linguistic competence the workbook has tasks for written translation of sentences and mini texts based on vocabulary and grammar of the unit.

To forge reading skills the workbook contains small texts with tasks for information extraction: true-false choice; multiple choice; completing a text with sentences; matching headline and text passages or small texts; text reconstruction.

Drill tests from the workbook have up to eight different assignments used in the workbook and in-class written assessment. There are keys and self-assessment framework. Students individually count the number of points and define their grade. Students gaining fewer than 60 points are recommended to revise the chapter.

Home tasks are an important part of foreign language acquisition process (Würffel, 2019). All workbook exercises, except for translation assignments, are provided with keys and intended for students' independent extra-curricular work. Students check to see if they have done exercises properly with the help of keys, in class a teacher follows students' performance of the exercise just as a fact and comments on some separate assignments which were frequent to make mistakes in or have difficulties with. Before working with the workbook a teacher gives instructions how to arrange individual independent work with the workbook more efficiently. Students are recommended not just to fill in the gaps, match sentence part or context matching text pieces, tick true/ false variants but, also, spell out all the exercise and text content for more sustainable pronunciation, lexical and grammatical skills. When checking home tasks with keys it is recommended to highlight mistakes, made while doing the task, with a text marker to quickly find them at the beginning of the class and discuss it with the teacher and other students of the academic group. Thereby a teacher accumulates data of mistakes in the given group and may again deep into some difficult to understand matters of the topic and recommend students some optional resources for revision. Studied material subdivision into daily portions is necessary as it is recommended not to do home tasks on the class's eve. 
In the ETK «Im Klartext A2» there is also a multimedia class programme compiled from audio and video texts for drilling. Their selection is based on vocabulary and grammar topics of the student's book. In class there are used selection criteria and methods to practice, which was worked out by Basina N.V. and Ionova A.M. (2016) considering Moscow State Institute of International Relations (University) of the Ministry of Foreign Affairs' requirements. Within the present module a particular attention is given to students' project work focused on presentations, small reports, posters, etc., as such assignment types are the most complicated and combine several skills and competences. (Funk, Kuhn, Skiba, Spaniel-Weise \& Wicke, 2017).

Considering in more detail the possibilities for students' independent work for pronunciation and lexicogrammatical skills, listening comprehension, oral and written speech competence. All the multimedia materials are stored as a separate course on the educational media platform ed.mgimo. the multimedia platform allows students' more effective practice within multimedia in-class work as well as independent work for revision, practice of the studied material and homework, which encourages the individualization principle in education. (Rösler, 2018). As the first training stage students can individually work at pronunciation and intonation, repeating phrase after the speaker unlimited number of times. It is possible to repeatedly watch and listed to audio selected by the course author according to the main course topics and students' competence. Drill tests are to do iteratively at any time. Thus, most routine practice forms may be changed into on-line format, and during classes and videoconferences more attention is possible to give to more complicated notions, oral speech skills, discussions, presentations, professional competences, oral translation, and students' co-practice with each other as well as their teacher.

Course block general layout in picture 2 .

Pic. 2 


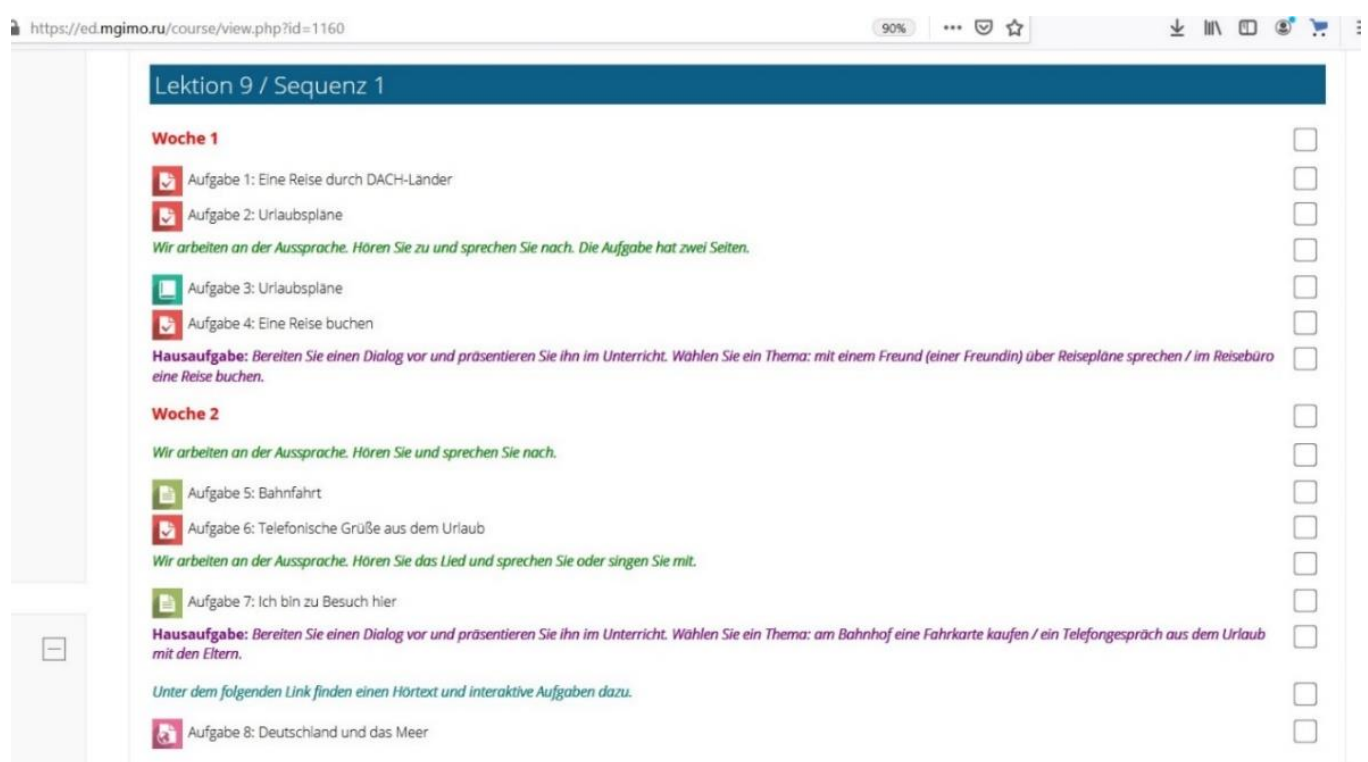

The multimedia platform advantage is a variety of task and practice forms with the following instruments: a page/ book, test, hyperlink, wiki, glossary, forum, task.

The 'page' or 'book' instrument allows text tasks to place, for example, a text or an article for rendering, a script, questionnaire, and to install a picture, audio, or video. The instrument is mostly used for auditive skills: a student listens to an audio file and simultaneously reads its script. Holding a pause, a student can repeat the text after the speaker, and within several attempts gain fluency following him.

The instrument 'test' includes all test types which are common to use in assessment papers - true/ false; a multiple choice; gap filling in or drag-and-drop texts; completing the missing affixes, prepositions, articles, numerals, translation equivalents, synonyms, antonyms, etc.; matching parts of phrases, wordcombinations, foreign words with their translations; phrase or text logical reconstruction. Tests may be of a drilling mode with unlimited number of attempts as well as assessment mode with one attempt only and time limit. After a drilling test, students have an opportunity to see correct answers after each attempt. In all the tests it is possible to place pictures, audio, and video. The instrument is used in the course for audio skills. Students listen to audio texts or watch a video piece to do different listening comprehension tasks.

Via hyperlink students can jump to such outside resources as Deutsche Welle, Deutsch-to-go, slowGerman, etc. for additional audio and video, and, if possible, tasks in the same resources with selfassessment. 
With the help of the wiki instrument students can co-create texts, questionnaires; answer together questions to a big size audio and video; rephrase sentences with some grammar structure (transference from active into passive voice, from present into past tenses, etc.); fill in lexical units with their translation and usage, synonyms, antonyms. In the bookmark 'history' a teacher may follow every user's contribution. A teacher may also edit notes, correct mistakes. The instrument 'glossary' gives a possibility to compile a glossary of lexical units, terms with their definitions, illustrations. All the course students and a teacher may leave comments. Wiki and glossary may be used both for mastering lexico-grammatical skills and written speech competence.

In the forum, students may express their opinion on the problem discussed and react to course mates' posts. In the instrument 'task' a teacher sets a task to create an oral or written text/ presentation. Students do it and submit it as a word, pdf, ppt file, or an audio file. The forum and task are meant for written speech assessment skill (Becker, 2018).

Despite a student's independent work on the education platform, a teacher has technical tools for controlling task performance, their correctness, a student's regular practice on the platform, instruments to correct mistakes in written papers and to comment on them.

\section{Discussions}

Foreign language as a discipline has a competence potential that is necessary for self-identification, selfregulation, and life-long learning and self-education in constantly changing modern social conditions. Academic autonomy development helps young people target and realise individual and collective objectives. The Federal State Education Standard provides for a student's particular in-class and independent practice portion in the curriculum. At the same time, a textbook or educational aid structure, including the most popular, do not always have the tasks to perform as out-class activities or fully independently performed, or partially under a teacher's supervision. Theoretical framework and practical instructions for textbooks and educational aids are urgent to work out, and, if necessary, for supplementary materials. That will allow a teacher to see a student's independent practice content amount. It is possible to support a teacher's book or educational aid instructions with this information. IT technologies, education platforms, in particular, are also effective in this respect. On the one hand, digital technologies are most common and natural for getting information and cooperation with other people for the present and next generations. On the other hand, they support education individualization, that is to individually set time, place, and duration of task performance, to receive in no time a system's feedback and check while doing a test. Finally, they save an interested students' time to have additional drill and information. Even though 
on-line course content is worked out on the basis of materials in the traditional format (texts, presentations, audio, video), it is necessary to arrange practical instructions for the content transformation onto multimedia platforms taking into account the specifics of universities, faculties, curricula. Moreover, creation of on-line courses goes together with difficulties of a technical character. A course arrangement demands a lot of time costs, the process itself is complicated because of variability of tasks and tests. Online content transformation is allowed only for the staff excellent at digital technologies, who are recommended to work as a team. Herewith, there is a need to train teachers to work on the platform, giving detailed instructions for such teachers and students within an extension training course.

\section{Conclusion}

The academic autonomy notion is deeply set in the domestic teacher training methodology and education process. It should be taken into consideration when compiling modern education aids and training kits. Independent work tasks may be part of a student's book (small dialogues, interviews, discussions, e-mails, blogs and other genres, information extraction tasks, written translation, oral translation on the spot), as well as a workbook (grammar and vocabulary exercises, readers with various tasks, drill tests). Digital resources have become an integral part of foreign language curriculum and are used both in in-class practice and as independent work tasks on education platforms. That allows students to measure the content for revision and drill at the same time for education individualization. The wide choice of instruments used on the course platform - a page, book, forum, test, glossary, wiki, task - and possible modes of single students' interaction, the whole group cooperation together with a teacher simulates interaction in real life situations and stimulates social skills. A detailed analysis of the present student's books and education aids is a further perspective to single out the components for students' independent practice. Academic autonomy should be taken into account as an education objective of the new education training kit concept.

\section{References}

Anikina, Zh.S. (2011). Uchebnaya avtonomiya kak neot'emlemyj komponent processa obucheniya inostrannomu yazyku $v$ XXI veke. [Academic autonomy as an integral part of foreign language education process in the XXI century.]. Vestnik Tomskogo gosudarstvennogo universiteta, 6 (108), $85-88$.

Becker, C. (2018). Kulturbezogenes Lernen in asynchroner computervermittelter Kommunikation. Tübingen: Narr Francke Attempto. 
Brash, B., Pfeil, A. (2018). Unterrichten mit digitalen Medien. Stuttgart: Ernst Klett Sprachen.

Feick, D. (2020) Ist das Kollaboration? Multimodale Aspekte von Gruppeninteraktionen in der Fremdsprache Deutsch. Deutsch als Fremdsprache, 2, 79-87.

Funk, H., Kuhn, C., Skiba, D., Spaniel-Weise, D., \& Wicke, R.E. (2017). Aufgaben, Übungen, Interaktion. Stuttgart: Ernst Klett Sprachen.

Grotjahn, R., \& Kleppin, K. (2018). Prüfen, Testen, Evaluieren. Stuttgart: Ernst Klett Sprachen.

Ionova, A.M., \& Bazina, N.V. (2016). Methodological framework for developing cultural studies tasks based on German television programs. The Turkish Online Journal of Design Art and Communication, 6 (S-NVSPCL), 3406-3411.

Kapaeva, A.E. (2001). O formirovanii gotovnosti uchashchihsya k samoobucheniyu inostrannym yazykam [Learners' readiness for foreign language self-education.]. Inostrannye yazyki v shkole, 3, 12-16.

Nasonova, E.A. (2010). Analiz interpretacii ponyatiya «uchebnaya avtonomiya» [Interpretaion analysis of the academic autonomy notion]. Izvestiya vuzov. Seriya «Gumanitarnye nauki», 1(2), 145-149.

Omelchenko, M.S., Khosainova, O.S., Mueller, J.E. (2021). Im Klartext. Arbeitsbuch. Chast' II. Uroven' A2: Uchebnoe posobie. Pod red. E.A. Ziminoj [Part 2: Education aid, ed. by Zimina E.A.]. Moskva: Prometej.

Printsipalova, O.V., Merkish, N.E., Kirina, T.P. (2021). Im Klartext. Kursbuch. Chast' II. Uroven' A2: Uchebnoe posobie. Pod red. E.A. Ziminoj [Part 2: Education aid, ed. by Zimina E.A.]. Moskva: Prometej.

Rösler, D. (2018). Lernerautonomie und digitale Medien. In: Japanische Gesellschaft für Germanistik (Hrsg.) Lernerautonomie und Lernstrategien zwischen Klassenraum und digitaler Welt Perspektiven auf das Deutschlernen in Japan. München: iudicium.

Rösler, D., \& Würffel, N. (2020). Lehr- und Lernmedien. Stuttgart: Ernst Klett Sprachen.

Solovova, E.N. (2013). Perspektivnye napravleniya razvitiya vuzovskoj metodiki prepodavaniya inostrannyh yazykov [Perspectives of foreign language higher education.]. Vestnik MGIMO Universiteta, 6(33), 67-70. 
Tareva, E.G., Yazykova, N.V. (2018). Faktory modernizacii shkol'nogo obrazovaniya v predmetnoj oblasti inostrannye yazyki [Modernising school education factors in foreign language teaching.]. Inostrannye yazyki $v$ shkole, 4, 2-8.

Würffel, N. (2019). Hausaufgaben im DaF/DaZ-Unterricht. Info DaF, 46 (5), 546-570. 